\title{
Distribution of excreted nitrogen by grazing cattle and its effects on sward quality, herbage production and utilization
}

\author{
E A LANTINGA ${ }^{\mathrm{a}}$, J A KEUNING ${ }^{\mathrm{b}}, \mathrm{J}_{\text { GROENWOLD }}{ }^{\mathrm{c}}$ and $\mathrm{P}$ J A G \\ DEENEN ${ }^{\mathrm{a}}$ \\ "Department of Field Crops and Grassland Science, Agricultural University, Haarweg 333, \\ 6709 RZ Wageningen, The Netherlands \\ ${ }^{b}$ Research Station for Cattle, Sheep and Horse Husbandry (PR), Runderweg 6, 8219 PK \\ Lelystad, The Netherlands (Seconded by the Netherlands Fertilizer Institute) \\ ${ }^{c}$ Centre for Agrobiological Research (CABO), P.O. Box 14,6700 AA Wageningen, The \\ Netherlands
}

Key words: grassland, grazing, nitrogen excretion, nitrogen response, botanical composition, herbage intake

\begin{abstract}
Grazing cattle exert positive and negative effects on pasture production. It is shown that at a fertilizer nitrogen (N) input of $200 \mathrm{~kg} \mathrm{~N} \mathrm{ha}^{-1} \mathrm{yr}^{-1}$ and more, the benefit from $\mathrm{N}$ circulation through urine and dung is not of significance for the pasture as a whole. Of the negative effects, poaching has the greatest influence on the response of pasture production to $\mathrm{N}$ fertilization.

Two one-year experiments, are described which showed that there were no significant differences in the response of grassland production to $\mathrm{N}$ fertilization between cutting and grazing usage above about $200 \mathrm{~kg} \mathrm{~N}^{-1} \mathrm{yr}^{-1}$.
\end{abstract}

\section{Introduction}

The supply of nitrogen $(\mathrm{N})$ to a grazed sward is increased by the uneven return of $\mathrm{N}$ via dung and urine. When available $\mathrm{N}$ is below the level needed to support maximum herbage growth, this return can stimulate local herbage production. However, grazing animals also cause sward damage through treading, poaching, fouling, urine scorch and sod-pulling. The impact of these negative effects increases with increasing fertilization levels $[4,26,27,32]$. This is associated with higher stocking rates and more vulnerable grass.

In this paper an attempt will be made to separate the positive and the negative effects of grazing cattle on sward quality, herbage production and utilization in pastures dominated by Lolium perenne. Furthermore, a comparison will be made between the response of herbage to fertilizer $\mathrm{N}$ under grazing or under cutting. 
The proportion of total $\mathrm{N}$ intake which is subsequently excreted or voided and its partition between urine and faeces depends on the type of cattle, the level of production, the intake of dry matter (DM) and the $\mathrm{N}$ concentration of the diet. The faeces of both beef and dairy cattle contain about $0.8 \mathrm{~g} \mathrm{~N}$ per $100 \mathrm{~g} \mathrm{DM}$ consumed [30]. This agrees with the findings in a continuous grazing experiment of the Agricultural University in the Flevopolders. Throughout the grazing season it was found that the faeces of dairy cows, consuming $1 \mathrm{~kg}$ of concentrates and about $16 \mathrm{~kg}$ of herbage DM daily, contained on average $132 \mathrm{~g} \mathrm{~N}$ cow $^{-1} \mathrm{day}^{-1}$. There appeared to be no influence of the level of $\mathrm{N}$ intake which varied between 450 and $775 \mathrm{~g} \mathrm{~N}$ cow $^{-1}$ day $^{-1}$.

One $\mathrm{kg}$ of liveweight gain in growing cattle contains about $30 \mathrm{~g} \mathrm{~N}$, whereas one $\mathrm{kg}$ of milk with a protein concentration of $3.4 \%$ contains about $5.5 \mathrm{~g} \mathrm{~N}$. This implies that beef cattle normally retain a lower percentage of the $\mathrm{N}$ ingested than do dairy cattle (Table 1).

Dairy cows tend to urinate and to defaecate twelve times per day [9]. Assuming that dairy cows spend about four hours per day off the pasture, about ten urinations and ten defaecations will be made onto the pasture by one cow.

The area influenced by urine is often more than twice the area actually wetted owing to diffusion of $\mathrm{N}$ in the soil and the lateral spread of roots [31]. With dairy cows it has been found that the area on which growth was stimulated averaged $0.68 \mathrm{~m}^{2}$ per urine patch and that a dung pat covered on average $0.05 \mathrm{~m}^{2}[10]$.

From the above data it follows that at 750 cow-grazing days ha ${ }^{-1} \mathrm{yr}^{-1}$ the total area directly affected by urine is $5100 \mathrm{~m}^{2} \mathrm{ha}^{-1} \mathrm{yr}^{-1}$ and by faeces $375 \mathrm{~m}^{2} \mathrm{ha}^{-1} \mathrm{yr}^{-1}$. However, there may be overlap, especially with urine. Using the negative binomial function of Petersen et al. [19], it can be calculated that with a rather uniform distribution of the excretions about $3900 \mathrm{~m}^{2} \mathrm{ha}^{-1} \mathrm{yr}^{-1}$ is affected by at least one urine excretion in the above

Table 1. Calculated example of the partition of ingested $\mathrm{N}$ between animal products, faeces and urine by beef cattle (liveweight gain $800 \mathrm{~g} \mathrm{steer}^{-1}$ day $^{-1}$ ) and dairy cattle (milk production $20 \mathrm{~kg} \mathrm{cow}^{-1} \mathrm{day}^{-1}$ ). Nitrogen concentration of the diet is $0.04 \mathrm{~g} \mathrm{~N}$ per $\mathrm{g} \mathrm{DM}$

\begin{tabular}{|c|c|c|c|c|c|c|}
\hline \multirow{2}{*}{\multicolumn{2}{|c|}{$\begin{array}{c}\text { Intake } \\
\mathrm{kg} \mathrm{DM} \mathrm{head}^{-1} \mathrm{day}^{-1}\end{array}$}} & intake & $\begin{array}{l}\mathrm{N} \text { in: } \\
\text { animal products }\end{array}$ & faeces & urine & \multirow[t]{2}{*}{$\begin{array}{l}\% \text { in faeces } \\
\text { and urine }\end{array}$} \\
\hline & & & \multicolumn{3}{|l|}{ gN head $^{-1}$ day $^{-1}$} & \\
\hline beef cattle & 8 & 320 & 24 & 64 & 232 & 93 \\
\hline dairy cattle & 16 & 640 & 110 & 128 & 402 & 83 \\
\hline
\end{tabular}


example. In a situation of a more uneven distribution, this is somewhat lower due to more overlap. This is to be expected with continuous grazing where a typical feature of low stocking densities is 'camping areas'.

From the previous data it can also be calculated that the average rate of $\mathrm{N}$ applied to an area affected by a urination from a daily intake of $16 \mathrm{~kg}$ herbage DM $(4 \% \mathrm{~N})$ is about $500 \mathrm{~kg} \mathrm{~N} \mathrm{ha}^{-1}$. Similarly, it follows that one dung dropping is equivalent to an application in the order of $2000 \mathrm{~kg} \mathrm{~N}$ $\mathrm{ha}^{-1}$.

\section{Dung}

\section{Positive effects}

Considering the extent to which $\mathrm{N}$ in faeces stimulates grass growth, MacLusky [14] observed that faeces affected the growth of herbage over an area about 6 times that actually covered. This agrees with the findings of MacDiarmid and Watkin [13]. They concluded that grasses growing up to $15 \mathrm{~cm}$ from the edge of a dung pat can derive $\mathrm{N}$ from the region under the pat owing to the lateral spread of grass roots. Assuming a mean area of a dung pat of $0.05 \mathrm{~m}^{2}$, this is equivalent to an affected area of about $0.25 \mathrm{~m}^{2}$. However, the direct response of herbage production to cattle dung is much smaller than that brought about by urine. This is because the release of inorganic $\mathrm{N}$ from dung is a relatively slow process. The visible effects of dung $\mathrm{N}$ may last for up to two years [24], but in total there is only a small beneficial effect on herbage production [33], certainly at moderate and high rates of fertilizer $\mathrm{N}\left(200 \mathrm{~kg} \mathrm{~N} \mathrm{ha}^{-1} \mathrm{yr}^{-1}\right.$ and more). This is also clear from Table 2, which shows no influence of dung pats on the $\mathrm{N}$ concentration of adjacent herbage [28]. However, in the long term dung $\mathrm{N}$ contributes significantly to the typical increase in soil $\mathrm{N}$ content under permanent pastures [25]. This in turn results in a gradually increasing level of net mineralization of $\mathrm{N}$. Unfortunately, data on this feature are lacking.

Table 2. Nitrogen concentration of herbage (g N per $100 \mathrm{~g}$ DM) growing inside and outside dung-affected areas at two $\mathrm{N}$ fertilization levels under continuous grazing

\begin{tabular}{llllll}
\hline Month & \multicolumn{2}{l}{$\mathrm{N}$ application, $\mathrm{kg} \mathrm{ha}^{-1} \mathrm{yr}^{-1}$} & & \\
\cline { 2 - 3 } & 214 & & 427 & not affected \\
\cline { 2 - 3 } \cline { 5 - 6 } & dung-affected & not affected & & dung-affected & 4.1 \\
June & 3.3 & 3.3 & 4.0 & 3.3 \\
\hline
\end{tabular}


Negative effects

The direct adverse effects of dung pats on herbage production are unimportant because of the small area covered and the possibility for exploitation of the space above the pats by adjacent plants [32]. The time required before dung has visually disappeared from a pasture depends on the weather and the activity of the soil fauna. On average, this is about three months and leaves a bare area. In pastures dominated by perennial ryegrass, recolonization takes place mainly by this species which has excellent tillering ability [2].

An indirect negative effect of dung is the rejection of herbage by grazing cattle in and adjacent to the contaminated area. This rejection is caused mainly by the smell of dung [16]. The size of the rejected area depends on the intensity of grazing, the rate of $\mathrm{N}$ fertilization [12] and possibly on the degree to which cows accustom themselves to eating dung-affected herbage [15]. On the other hand, it is remarkable that cows are quite prepared to graze close to fresh faeces, but that they avoid partly decomposed faeces [7]. Moreover, not every dung dropping causes rejection of surrounding herbage. Keuning [11] observed in September 1975 that after three rotational grazing periods in June, July and August, only 45 out of 98 dung pats gave rise to rejected patches, 38 in total with a mean area of $0.56 \mathrm{~m}^{2}$. In particular, small dung pats $\left(1-2 \mathrm{dm}^{2}\right)$ did not cause rejected patches. Visual observations indicated that on areas where dung pats were grouped, large rejected patches were found.

When there is a surplus of herbage, grazing cattle reject herbage around dung pats to a large extent. Eventually, when no silage cuts are taken or the fouled area is not topped, the pasture is covered with clumps of long rank herbage. This situation should be avoided because the ungrazed herbage becomes mature and will then be neglected due to differences in palatability rather than to the proximity of dung [18]. Moreover, tiller density in rejected areas will decrease gradually, giving rise to sward deterioration. It normally takes three to four months before herbage around dung pats is grazed down to the same level as surrounding pasture [29].

With carefully controlled continuous grazing, the rejected area can be minimized. The height of herbage around dung pats is kept at an acceptable level since the upper parts of the herbage in these areas are grazed regularly. In a current experiment by the Department of Field Crops and Grassland Science in the Flevopolders, where the mean sward height between dung affected areas is kept at about $5 \mathrm{~cm}$, at maximum $15 \%$ of the area carrying herbage with a height not exceeding $15 \mathrm{~cm}$ is more or less rejected throughout the grazing season. Under this management herbage intake is sufficient for an average production of $22 \mathrm{~kg}$ fat-corrected milk cow ${ }^{-1}$ day $^{-1}$ between 
May and October. The sward height is measured using a falling disc with a diameter of $50 \mathrm{~cm}$ and a weight of $340 \mathrm{~g}$.

It is interesting to note that Greenhalgh and Reid [7] found that the daily intake of organic matter by grazing dairy cows was equally reduced by fouling at a low and at a high grazing intensity. At both grazing intensities the intake on previously grazed and topped paddocks was about $9 \%$ below that on previously cut paddocks. However, the daily intake of digestible organic matter and the fat-corrected milk production were not significantly reduced by fouling. This was because for some reason the herbage growing on the fouled pasture had a higher digestibility. The question remains what the influence of fouling would have been at equal digestibilities. In another experiment (Lantinga, unpublished) it was found that the relationship between daily herbage allowance and daily herbage intake per steer was the same for the first and the second grazing period in paddocks which were not topped after the first grazing. The results of these two experiments suggest that at corresponding herbage allowance levels cattle in fouled pastures can be forced to graze close to dung pats without reducing the individual intake significantly in comparison with clean pastures. However, this topic needs further research. Under a management system whereby cuts are taken for conservation, the alternation of mowing and grazing ensures better utilization of the herbage [14].

\section{Urine}

\section{Positive effects}

Normally, urine has a beneficial effect on herbage growth, especially in dry periods. The growth stimulation may be due either to urine potassium (K) or $\mathrm{N}$ [3]. In this paper only the $\mathrm{N}$ effects will be considered.

The $\mathrm{N}$ in cattle urine is present mainly as urea. After excretion there is a very rapid hydrolysis of urea into ammonium salts in the soil [8]. In the high $\mathrm{pH}$ environment generated by the hydrolysis of urea, ammonium is subject to ammonia volatilization. Hydrolysis is usually complete within one to three days of urine deposition [25]. The ammonium remaining in the soil is generally nitrified into nitrate. Both ammonium and nitrate can be absorbed and assimilated by the standing herbage and stimulate production of harvestable DM. The urine- $\mathrm{N}$ effects may last for about five months when applied in spring and for about ten months when applied in autumn $[10,18]$. Except on very light soils, autumn depositions of urine may give rise to heterogeneity in pasture growth in the following spring (Keuning, un- 
published). However, the increase in yield following autumn application has been found to be lower than that following spring application due to winter leaching of $\mathrm{N}$ [18].

The extent to which urine $\mathrm{N}$ can stimulate $\mathrm{DM}$ production is dependent on the level of fertilizer $\mathrm{N}$ input. To study this, the Department of Field Crops and Grassland Science has started research on the response of pasture production to $\mathrm{N}$ fertilization under continuous and rotational grazing. From the results collected in 1985 on a clay soil in the Flevopolders an estimation can be made of the positive effects of urine $\mathrm{N}$ at an annual fertilizer rate of $250 \mathrm{~kg} \mathrm{~N} \mathrm{ha}^{-1}$.

The $\mathrm{N}$ response was measured during one grazing season with continuous grazing at two $\mathrm{N}$ levels ( 250 and $550 \mathrm{~kg} \mathrm{~N} \mathrm{ha}^{-1} \mathrm{yr}^{-1}$ ) and with weekly cutting over a range up to $700 \mathrm{~kg} \mathrm{~N} \mathrm{ha}^{-1} \mathrm{yr}^{-1}$. It was hypothesized that the defoliation regime under continuous grazing could be simulated with weekly cutting. At $250 \mathrm{~kg} \mathrm{~N} \mathrm{ha}^{-1} \mathrm{yr}^{-1}, 695 \mathrm{cow}$-grazing days $\mathrm{ha}^{-1} \mathrm{yr}^{-1}$ were attained. The potential effect of urine $\mathrm{N}$ on DM production was estimated by making use of dynamic simulation. The following assumptions were made: (i) one cow affects $6.8 \mathrm{~m}^{2}$ of the pasture daily by urine; (ii) the urine $\mathrm{N}$ is effective for five months; (iii) during this period the DM production in urine-affected areas is enhanced by the measured difference in DM production under weekly cutting at 700 and $250 \mathrm{~kg} \mathrm{~N} \mathrm{ha}^{-1} \mathrm{yr}^{-1}$. With $700 \mathrm{~kg} \mathrm{~N}$ $\mathrm{ha}^{-1} \mathrm{yr}^{-1}$ the DM production appeared to be close to its maximum under weekly cutting (Lantinga, unpublished). The simulation yielded a potential increase in pasture production due to urine $\mathrm{N}$ at $250 \mathrm{~kg}$ fertilizer $\mathrm{N} \mathrm{ha}^{-1} \mathrm{yr}^{-1}$ of about $1200 \mathrm{~kg} \mathrm{DM} \mathrm{ha}^{-1}$. Such an increase is noteworthy. However, the actual increase can only have been a fraction of this, since:

- it is now known that the response of DM production to a range of fertilizer $\mathrm{N}$ levels is greater with weekly cutting than with continuous grazing (Lantinga, unpublished);

- overlapping of urine patches occurs;

- the whole affected area will not give maximum production;

- maximum production will be realized only during a part of the five months period;

- not all excretions will stimulate DM production, with scorching as the extreme.

Taking these points into account, we estimate that in reality not more than about one-quarter of the calculated potential increase can have occurred. It will be clear that an increase in the order of $300 \mathrm{~kg} \mathrm{DM} \mathrm{ha}^{-1} \mathrm{yr}^{-1}$ is not of significance and, moreover, that it is impossible to measure such an increase in whole-paddock trials. 


\section{Negative effects}

In contrast with dung, urine-affected areas are not rejected at all by grazing cattle. Keuning (unpublished) observed in paddocks which were grazed for one day, that at the end of the day the urine-affected areas were grazed down to the same level as the non-affected areas. Norman and Green [18] observed that urine-affected areas were grazed in preference after some weeks of regrowth.

Scorching and death of grass within areas affected by urine is a serious problem in intensively managed pastures grazed by cattle. Research in The Netherlands by Keuning (reported in [26]) revealed that the occurrence of urine scorch is greatest if the soil is moist and the average daily temperature is between approximately 15 and $20^{\circ} \mathrm{C}$. Urine scorch is a more serious problem on sandy soils than on peat and clay soils and the extent is strongly correlated with the rate of fertilizer $\mathrm{N}$ (Table 3).

Groenwold and Keuning [9] observed that any cow can cause urine scorch. However, there appeared to be a large difference in extent of the damage between cows. This was related to differences in the chemical composition of the urine (Table 4). In another experiment it was found that the urinations during morning hours caused more damage than those later in the day (Table 5). This was also associated with differences in the chemical composition of the urine.

It was first shown by Richards and Wolton [23] that the scorching effect of urine is exerted on the root system of the grass and not on the foliage. Of the components which are formed during the hydrolysis of urine in the soil, ammonium-ions seem to be the most toxic to grass roots [8].

Urine scorch may lead to a deterioration in botanical composition. Richards and Wolton [23] observed that in patches where only a few grass tillers had been killed, the patches filled in with Lolium perenne before the end of the season. However, on the clay soil of their experiments, colonization of

Table 3. Effect of $\mathrm{N}$ fertilization on urine scorch (in $\%$ of the total area per year)

\begin{tabular}{lllllll}
\hline Soil type & \multicolumn{2}{l}{$\mathrm{kg} \mathrm{N} \mathrm{ha}^{-1} \mathrm{yr}^{-1}$} & & & & \\
\cline { 2 - 6 } & 0 & 150 & 200 & 300 & 400 & 600 \\
\hline $\begin{array}{l}\text { Peat soil } \\
\begin{array}{l}\text { average } \\
1977-1981\end{array}\end{array}$ & 0.2 & 0.8 & & 1.5 & & 4.2 \\
$\begin{array}{l}\text { Sandy soil } \\
\begin{array}{l}\text { average } \\
1980-1983\end{array}\end{array}$ & & & & & \\
\hline
\end{tabular}


Table 4. Variations between cows in urine composition in relation to scorching. Urine samples were collected on 8 days during the grazing season of 1979. Permanent pasture on peat soil; $1000 \mathrm{~kg}$ fertilizer $\mathrm{N} \mathrm{ha}^{-1} \mathrm{yr}^{-1}$

\begin{tabular}{|c|c|c|c|c|c|c|c|c|c|}
\hline \multirow[t]{2}{*}{ Cow } & \multirow{2}{*}{$\begin{array}{l}\text { Conductivity } \\
\left(\mathrm{mS} \mathrm{cm}^{-1}\right)\end{array}$} & \multirow{2}{*}{$\begin{array}{l}\text { Hippuric acid } \\
\left(\mathrm{gl}^{-1}\right)\end{array}$} & \multirow{2}{*}{$\begin{array}{l}\text { Urea } \\
\left(\mathrm{g}^{-1}\right)\end{array}$} & \multirow{2}{*}{$\begin{array}{l}\text { Total N } \\
\left(\mathrm{g}^{-1}\right)\end{array}$} & \multirow{2}{*}{$\begin{array}{l}\text { Patches with } \\
\text { scorching (\%) }\end{array}$} & \multicolumn{3}{|c|}{ Scale of scorching (\%) } & \multirow{2}{*}{$\begin{array}{l}\text { Average area } \\
\text { damaged per scorched } \\
\text { patch }\left(\mathrm{dm}^{2}\right)\end{array}$} \\
\hline & & & & & & light & medium & severe & \\
\hline 47 & 16.4 & 6.8 & 16.0 & 8.9 & 46 & 27 & 27 & 46 & 10 \\
\hline 89 & 12.3 & 5.3 & 10.9 & 6.1 & 24 & 33 & 54 & 13 & 18 \\
\hline 156 & 15.1 & 6.6 & 14.2 & 7.4 & 69 & 55 & 36 & 9 & 7 \\
\hline 167 & 16.7 & 8.6 & 17.6 & 9.7 & 86 & 12 & 44 & 44 & 18 \\
\hline
\end{tabular}

Table 5. Effect of time of the day on urine composition in relation to urine scorching. Three periods of 36 to 48 hours were studied during July and

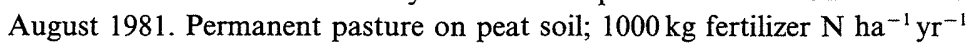

\begin{tabular}{|c|c|c|c|c|c|c|c|c|c|}
\hline \multirow{2}{*}{$\begin{array}{l}\text { Time of } \\
\text { the day } \\
\text { (h) }\end{array}$} & \multirow{2}{*}{$\begin{array}{l}\text { Conductivity } \\
\left(\mathrm{mS} \mathrm{cm}^{-1}\right)\end{array}$} & \multirow{2}{*}{$\begin{array}{l}\text { Hippuric acid } \\
\left(\mathrm{g}^{-1}\right)\end{array}$} & \multirow{2}{*}{$\begin{array}{l}\text { Urea } \\
\left(\mathrm{g} 1^{-1}\right)\end{array}$} & \multirow{2}{*}{$\begin{array}{l}\text { Total N } \\
\left(\mathrm{g} 1^{-1}\right)\end{array}$} & \multirow{2}{*}{$\begin{array}{l}\text { Patches with } \\
\text { scorching (\%) }\end{array}$} & \multicolumn{3}{|c|}{ Scale of scorching $(\%)$} & \multirow{2}{*}{$\begin{array}{l}\text { Average area } \\
\text { damaged per scorched } \\
\text { patch }\left(\mathrm{dm}^{2}\right)\end{array}$} \\
\hline & & & & & & light & medium & severe & \\
\hline $06-12.00$ & 21.3 & 5.7 & 16.0 & 11.1 & 79 & 21 & 26 & 53 & 20 \\
\hline $12-18.00$ & 20.6 & 6.8 & 13.5 & 9.8 & 59 & 22 & 43 & 35 & 17 \\
\hline $18-24.00$ & 16.4 & 6.0 & 11.7 & 8.4 & 54 & 33 & 33 & 33 & 17 \\
\hline $24-06.00$ & 19.4 & 6.0 & 14.9 & 10.4 & 68 & 29 & 47 & 24 & 15 \\
\hline
\end{tabular}


Table 6. Botanical composition after four years redevelopment in completely killed urine patches

\begin{tabular}{lll}
\hline Species & $\begin{array}{l}\text { Percentage of } \\
\text { total DM }\end{array}$ & $\begin{array}{l}\text { Percentage } \\
\text { ground cover }\end{array}$ \\
\hline Lolium perenne & 44 & 55 \\
Poa trivialis & 16 & 13 \\
Poa annua & 13 & 9 \\
Alopecurus geniculatus & 4 & 5 \\
Elymus repens & - & 1 \\
Other grass species & 1 & 3 \\
Taraxacum officinale & 21 & 13 \\
Other herbs & 1 & 1 \\
\hline
\end{tabular}

completely killed patches was mainly by Poa annua, Plantago major, Rumex obtusifolius and Sonchus oleraceus. Keuning and Groenwold [10] followed the change in botanical composition of scorched patches on a sandy soil over a period of four years. At the beginning of the experiment the pasture comprised more than $90 \%$ Lolium perenne on a dry weight basis. The regrowth on scorched patches consisted mainly of Poa annua and partly of Stellaria media and Taraxacum officinale. Fifteen months after development of the patches Lolium perenne increased to $25 \%$, but Poa annua was still the most important species. In the following years the botanical composition improved gradually, but did not reach the previous sward quality (Table 6).

Urine scorch will diminish if water intake by the cattle is increased. To this end, Keuning and Groenwold (unpublished) examined the effect of adding molasses to the drinking water. In 1983 , when a $2 \%$-solution of molasses was supplied $a d l i b$. to grazing yearlings, the results were very promising. The average daily intake of molasses-water was 57.81 head $^{-1}$, whereas the controls consumed only 21.61 water head ${ }^{-1} \mathrm{day}^{-1}$. This resulted in a decrease of the scorched area by $57 \%$. The $\mathrm{N}$ concentration of the urine from the yearlings drinking molasses-water averaged $3.68 \mathrm{~g}^{-1}$ and that from the control group $8.65 \mathrm{~g}^{-1}$. In 1984 and 1985 the experiment was repeated with milking cows. Surprisingly no differences were established in the water consumption and consequently neither in the extent of urine scorch. In the autumn of both years the experiment was continued with yearlings and the same effect was obtained as in 1983. It is not known why yearlings and milking cows showed such different reactions.

\section{Response of pasture production to nitrogen fertilization}

Fertilizer $\mathrm{N}$ plays an important role in intensive grassland management. The economic use of this input depends upon the response to the applied $\mathrm{N}$, 
either in terms of herbage DM production or animal products. Experimental data in the literature on the yield response to $\mathrm{N}$ under grazing are scanty and often conflicting. This is due partly to the fact that measurement of herbage DM production under grazing can only be done using indirect techniques.

At present, the Dutch standard fertilizer recommendation for grassland on clay and sandy soils is $400 \mathrm{~kg} \mathrm{~N} \mathrm{ha}^{-1} \mathrm{yr}^{-1}$ [20]. This recommendation is based principally on trials where the response of $\mathrm{DM}$ production to $\mathrm{N}$ fertilization was evaluated under a mean 4-weekly cutting interval. However, grazing animals exert positive effects on DM production due to the recycling of nutrients, as well as negative effects. In order to maintain individual animal performance and to counteract sward deterioration when sward damage occurs, stocking density has to be decreased which tends to reduce annual pasture yields. This effect is well illustrated by the results of field experiments carried out in the 1970s and 1980s at North Wyke (Devon, UK), a site with a high risk of poaching. Both Richards [22] and Wilkins (personal communication) observed on grazed swards no further response to $\mathrm{N}$ above $300 \mathrm{~kg} \mathrm{~N} \mathrm{ha}^{-1} \mathrm{yr}^{-1}$. However, on swards cut at 4-weekly intervals at the same site, the DM yield reached a maximum at about $600 \mathrm{~kg} \mathrm{~N}$ $\mathrm{ha}^{-1} \mathrm{yr}^{-1}$. In both experiments there was considerable herbage soiling and poaching damage on the grazed swards at high rates of $\mathrm{N}$. This was most obvious during wet conditions in the spring.

Other factors which may influence the response of herbage yield to $\mathrm{N}$ fertilization are the supply of phosphorus (P) and $\mathrm{K}$ and the botanical composition. At increasing concentrations of herbage $\mathrm{N}$, the required concentrations in herbage of both $\mathrm{P}$ and $\mathrm{K}$ also increase [21]. In England and Wales, a $\mathrm{K}$ concentration of $20 \mathrm{~g}(\mathrm{~kg} \mathrm{DM})^{-1}$ is regarded as sufficient for good grass growth [21]. However, trials by Arnold [1] revealed that at $\mathrm{N}$ concentrations around $30 \mathrm{~g}(\mathrm{~kg} \mathrm{DM})^{-1}$, a $\mathrm{K}$ concentration of $20 \mathrm{~g}$ $(\mathrm{kg} \mathrm{DM})^{-1}$ depressed annual herbage yield by more than $5 \%$. According to Prins et al. [21], at an average $\mathrm{N}$ concentration of $30 \mathrm{~g}(\mathrm{~kg} \mathrm{DM})^{-1}$ a $\mathrm{K}$ concentration of over $30 \mathrm{~g}(\mathrm{~kg} \mathrm{DM})^{-1}$ is required. For this reason, it is possible that in some of the research carried out in England and Wales, the response of grassland production to fertilizer $\mathrm{N}$ supply has been reduced by a suboptimal K supply.

In the research by the Department of Field Crops and Grassland Science in the Flevopolders, mentioned before, the swards comprised more than $90 \%$ Lolium perenne on a dry weight basis, the $\mathrm{P}$ and $\mathrm{K}$ supply was good and there had been no poaching damage and hardly any urine scorch since the start in 1984. Only damage due to sod-pulling has appeared to be of significance, at least visually and especially during late summer at high $\mathrm{N}$ fertilizer. However, Tallowin et al. [27] found that, even at high $\mathrm{N}$ levels, 
sod-pulling does not lead to a serious loss of herbage DM. In 1984 and 1985 the $\mathrm{N}$ response was evaluated in one-year trials under continuous grazing or cutting. In one of the cutting treatments, the herbage was harvested when a yield of about $2000 \mathrm{~kg} \mathrm{DM} \mathrm{ha}{ }^{-1}$ above a cutting height of $5 \mathrm{~cm}$ was reached. This cutting regime is comparable with that applied by Prins [20]. In both years the response of pasture production to $\mathrm{N}$ fertilization was evaluated at two $\mathrm{N}$ levels (1984: 214 and $427 \mathrm{~kg} \mathrm{~N} \mathrm{ha}^{-1} \mathrm{yr}^{-1} ; 1985: 250$ and $550 \mathrm{~kg} \mathrm{~N} \mathrm{ha}^{-1} \mathrm{yr}^{-1}$ ). The number of animals on each area was adjusted throughout the grazing season when necessary to maintain a mean sward

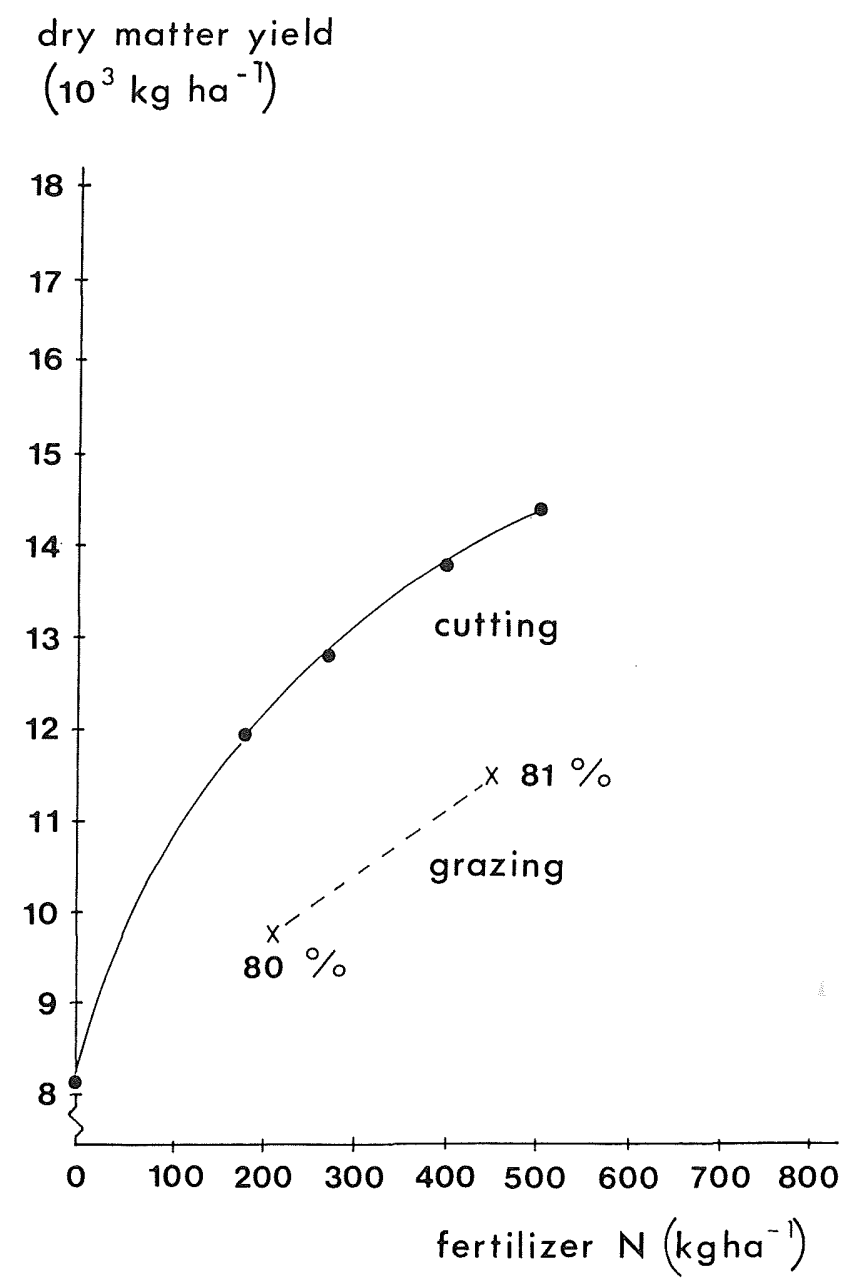

Figure 1. Effect of $\mathrm{N}$ fertilization on herbage DM yield under continuous grazing (weekly moved cages) and cutting (mean 4-weekly cutting interval). Yields under grazing are also expressed as a percentage of those under cutting at corresponding N levels. Swifterbant, 1984. 
height of about $6 \mathrm{~cm}$. In 1985 the yields under grazing and cutting were compared on the basis of herbage DM production. Under continuous grazing the production was measured by using exclusion cages which were moved weekly [6]. In 1985 the $\mathrm{N}$ response under grazing and cutting was compared on basis of the Dutch net energy system [5]. In this system the energy value of the herbage and the animal requirements are expressed in Dutch feed units for lactation (VEM). One VEM contains $6.9 \mathrm{~kJ}$ net energy for lactation (NEL). Under cutting the VEM yield was calculated from

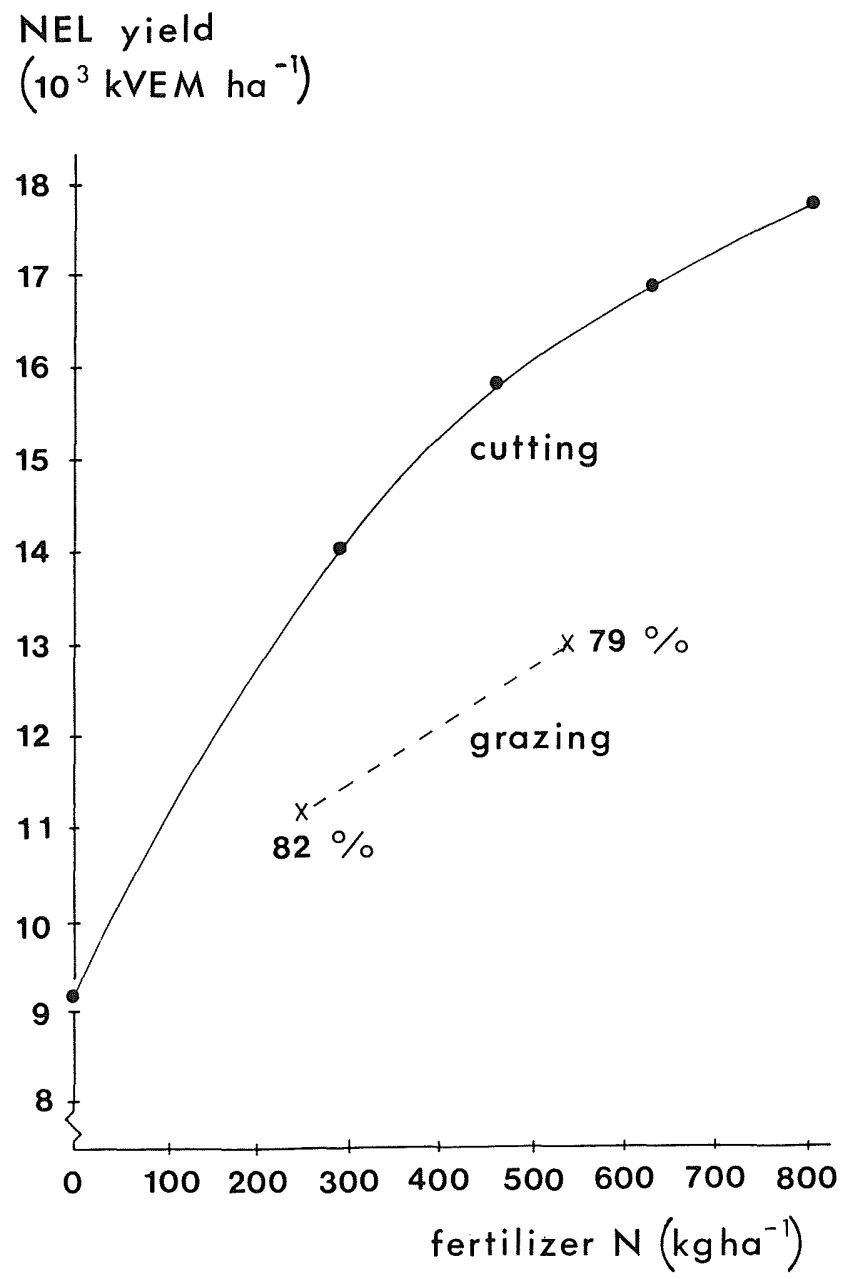

Figure 2. Response of NEL yield to $\mathrm{N}$ fertilization under continuous grazing (animal performance) and cutting (mean 4-weekly cutting interval). NEL: Net Energy for Lactation expressed in $\mathrm{kVEM} ; 1 \mathrm{kVEM}=6.9 \mathrm{MJ}$. Yields under grazing are also expressed of those under cutting at corresponding N levels. Swifterbant, 1985. 
harvested DM and chemical analyses. The VEM yield under grazing was calculated from animal production data using established standards for production and maintenance [17]. In both years the yields under grazing at both the low and the high levels of fertilizer $\mathrm{N}$ were about $80 \%$ of those obtained under cutting (Figs. 1 and 2). This suggests that:

(i) at the low fertilizer $\mathrm{N}$ rates there were no significant positive effects of the $\mathrm{N}$ returned by the grazing stock, as concluded before;

(ii) at the high fertilizer- $\mathrm{N}$ rates the negative effects exerted by the grazing cattle were not of significance.

The difference of about $20 \%$ in yield reflects the lower utilization efficiency of produced DM under grazing with respect to cutting [12].

In optimizing $\mathrm{N}$ fertilization, it is important to know the limit above which the yield increase does not pay for the extra $\mathrm{N}$ input. Prins [20] assumed that the 'optimum' rate of $\mathrm{N}$ application is at a marginal profitability of $7.5 \mathrm{~kg} \mathrm{DM}$ per $\mathrm{kg} \mathrm{N}$ applied. In long-term cutting trials on sand and clay soils the 'optimum' application appeared to be $420 \mathrm{~kg} \mathrm{~N} \mathrm{ha}^{-1} \mathrm{yr}^{-1}$. Corré and Dijkman (personal communication) observed in two consecutive years on a clay soil, that under a management system involving alternate grazing and silage cutting the marginal yield response was $7.5 \mathrm{~kg}$ DM per $\mathrm{kg}$ $\mathrm{N}$ applied at a fertilizer rate of about $400 \mathrm{~kg} \mathrm{~N} \mathrm{ha}^{-1} \mathrm{yr}^{-1}$. In this experiment there were also no problems with sward deterioration. The measured $\mathrm{N}$ response curves between 250 and $750 \mathrm{~kg}$ fertilizer $\mathrm{N} \mathrm{ha}^{-1} \mathrm{yr}^{-1}$ were very similar to those given by Prins [20] for clay soils under cutting only.

From the above experiments it may be concluded that for at least one growing season the response of grassland production to $\mathrm{N}$ fertilization will not differ significantly between cutting and grazing above about $200 \mathrm{~kg} \mathrm{~N}$ $\mathrm{ha}^{-1} \mathrm{yr}^{-1}$.

\section{References}

1. Arnold G H (1978) Potassium regime, dry matter yield, and magnesium content of grass. Proceedings of the 7th General Meeting of the European Grassland Federation (Ghent), pp 9.42-9.53

2. Castle M E and MacDaid E (1972) The decomposition of cattle dung and its effect on pasture. Journal of the British Grassland Society 27, 133-137

3. During C and McNaught K J (1961) Effects of cow urine on growth of pasture and uptake of nutrients. New Zealand Journal of agricultural Research 4, 591-605

4. Edmond D B (1966) The influence of animal treading on pasture growth. Proceedings of the 10th International Grassland Congress (Helsinki), 453-458

5. Es A J H van (1978) Feed evaluation for ruminants. I. The system in use from May 1977 onwards in the Netherlands. Livestock Production Science 5, 331-345

6. Frame J (1981) Herbage mass. In Hodgson J, Baker R D, Davies A, Laidlaw A S and 
Leaver J D, eds. Sward measurement handbook, pp 39-69. Hurley, UK: The British Grassland Society

7. Greenhalgh J F D and Reid G W (1969) The effects of grazing intensity on herbage consumption and animal production. III. Dairy cows grazed at two intensities on clean and contaminated pasture. Journal of Agricultural Science (Cambridge) 72, 223-228

8. Groenwold J and Heringa J W (1981) Urinebrandplekken in grasland. 2. Samenstelling van koeie-urine en omzettingen in de grond. Bedrijfsontwikkeling 12, 459-462

9. Groenwold J and Keuning J A (in prep.) Urinebrandplekken in grasland. III. Chemische processen

10. Keuning $\mathbf{J} \mathbf{A}$ and Groenwold $\mathbf{J}$ (in prep.) Urinebrandplekken in grasland. I. Botanische aspecten

11. Keuning J A and Vellinga Th V (1986) Zodekwaliteit en botanische samenstelling bij intensieve graslandexploitatie. Gebundelde Verslagen No. 27, pp 1-14. Wageningen, The Netherlands: Nederlandse Vereniging voor Weide- en Voederbouw

12. Lantinga E A (1985) Productivity of grasslands under continuous and rotational grazing. Doctoral thesis, Agricultural University, Wageningen

13. MacDiarmid B N and Watkin B R (1972) The cattle dung patch. II. Effect of a dung patch on the chemical status of the soil, and ammonia losses from the patch. Journal of the British Grassland Society 27, 43-48

14. MacLusky D S (1960) Some estimates of the areas of pasture fouled by the excreta of dairy cows. Journal of the British Grassland Society 15, 181-188

15. Marsh R and Campling R C (1970) Fouling of pastures by dung. Herbage Abstracts 40, $123-130$

16. Marten G C and Donker J D (1966) Animal excrement as a factor influencing acceptability of grazed forage. Proceedings of the 10th International Grassland Congress (Helsinki), 359-361

17. Meijs J A C (1981) Herbage intake by grazing dairy cows. Agricultural Research Report 909. Wageningen, The Netherlands: Centre for Agricultural Publishing and Documentation

18. Norman M J T and Green J O (1958) The local influence of cattle dung and urine upon the yield and botanical composition of permanent pasture. Journal of the British Grassland Society $13,39-45$

19. Petersen R G, Lucas H L and Woodhouse W W (1956) The distribution of excreta by freely grazing cattle and its effect on pasture fertility. I. Excretal distribution. Agronomy Journal 48, 440-449

20. Prins W H (1983) Limits to nitrogen fertilizer on grassland. Doctoral thesis, Agricultural University, Wageningen

21. Prins W H, Boer D J den and Burg P F J van (1986) Requirements for phosphorus, potassium and other nutrients for grassland in relation to nitrogen usage. In Cooper J P and Raymond W F, eds. Grassland Manuring. Occasional Symposium No. 20 (London), pp 28-45. Hurley, UK: The British Grassland Society

22. Richards I R (1977) Influence of soil and sward characteristics on the response to nitrogen. In Gilsenan B, ed. Animal production from temperate grassland. Proceedings of an international Meeting (Dublin), pp 45-49. Dublin, Ireland: Irish Grassland and Animal Production Association

23. Richards I R and Wolton K M (1975) A note on urine scorch caused by grazing animals. Journal of the British Grassland Society 30, 187-188

24. Richards I R and Wolton K M (1976) The spatial distribution of excreta under intensive cattle grazing. Journal of the British Grassland Society 31, 89-92

25. Ryden J C (1984) The flow of nitrogen in grassland. Proceedings No. 229. London, UK: The Fertiliser Society

26. Schechtner G, Tunney H, Arnold G H and Keuning J A (1980) Positive and negative 
effects of cattle manure on grassland with special reference to high rates of application. In Prins W H and Arnold G H, eds. The role of nitrogen in intensive grassland production. Proceedings of an international Meeting of the European Grassland Federation (Wageningen), pp 77-93. Wageningen, The Netherlands: PUDOC

27. Tallowin J R B, Kirkham F W and Brookman S K E (1986) Sward damage by sod-pulling - the effect of nitrogen. In Frame J, ed. Grazing. Occasional Symposium No. 19 (Great Malvern), pp 44-48. Hurley, UK: The British Grassland Society

28. Valk $\mathrm{H}$ and Ramshorst $\mathrm{H}$ van (1986) Bepaling van de grasopname van melkkoeien bij standweiden op twee verschillende stikstofniveaus. Doctoraal verslag. Wageningen, The Netherlands: Agricultural University

29. Weeda W C (1967) The effect of cattle dung patches on pasture growth, botanical composition and pasture utilisation. New Zealand Journal of agricultural Research 10, 150-159

30. Whitehead D C (1970) The role of nitrogen in grassland productivity. Commonwealth Bureau of Pastures and Field Crops, Bulletin 48. Hurley, UK: Commonwealth Agricultural Bureaux

31. Whitehead D C (1986) Sources and transformations of organic nitrogen in intensively managed grassland soils. In Meer H G van der, Ryden J C and Ennik G C, eds. Nitrogen fluxes in intensive grassland systems, pp 47-58. Dordrecht, The Netherlands: Martinus Nijhoff Publishers

32. Wilkins R J and Garwood E A (1986) Effects of treading, poaching and fouling on grassland production and utilization. In Frame J, ed. Grazing. Occasional Symposium No. 19 (Great Malvern), pp 19-31. Hurley, UK: The British Grassland Society

33. Wolton K M (1979) Dung and urine as agents of sward change: a review. In Charles A $\mathrm{H}$ and Haggar $\mathrm{R} J$, eds. Changes in sward composition and productivity. Occasional Symposium No. 10 (York), pp 131-135. Hurley, UK: The British Grassland Society 
